\title{
Vulnerability Analysis of the Coastal Sandy Aquifers in the East Coast of Sri Lanka with Recharge Change Consideration
}

\author{
Meththika Vithanage $^{1, *}$, Karen Villholth ${ }^{2}$, Peter Engesgaard ${ }^{3}$ and Karsten H. Jensen ${ }^{3}$ \\ ${ }^{I}$ Chemical and Environmental Systems Modelling Research Group, Institute of Fundamental Studies, Hantana Road, \\ Kandy, Sri Lanka \\ ${ }^{2}$ Geological Survey of Denmark and Greenland, Copenhagen, Denmark \\ ${ }^{3}$ Department of Geography and Geology, University of Copenhagen, Copenhagen, Denmark
}

\begin{abstract}
Groundwater is the only source of water for domestic as well as agricultural purposes in the sand aquifer in between sea and lagoon configuration typically found in the eastern Sri Lanka. This study was carried out to estimate the safe yield and assess the vulnerability of the sandy aquifer on the eastern coastal belt of Sri Lanka by rapid urbanization, agriculture and as well as climate change. A typical aquifer system was modeled as a part of a synthetic study to understand the sustainability of these coastal aquifers based on the observations made through a pilot field site in the eastern coastal sand stretch in Sri Lanka. Two dimensional model simulations were carried out representing $2000 \mathrm{~m}$ length, $22 \mathrm{~m}$ deep and $2 \mathrm{~m}$ wide model domain respectively. The safe yield of the aquifer is estimated to be $0.37 \mathrm{~m}^{3} / \mathrm{m}^{2}$ for an average hydrological year and $0.18 \mathrm{~m}^{3} / \mathrm{m}^{2}$ for a dry hydrological year. Water balance in the aquifer system is in equilibrium with the present recharge. However, it is important that the wells to be placed at least $750 \mathrm{~m}$ inland from the sea and lagoon respectively to avoid salt and brackish water intrusion. According to the modeling results, currently the aquifer system shows no signs of depletion or sea water intrusion. However, increase of population, increase of pumping, and reduction of recharge due to climate change can increase the aquifer vulnerability for contamination by salt and brackish water.
\end{abstract}

Keywords: Saltwater intrusion, groundwater pumping, safe yield, variable density flow modeling.

\section{INTRODCUTION}

Groundwater is regarded as a renewable natural resource if it exists in balance between recharge and extraction. Certain problems have beset the use of groundwater all around the world. The demand for water is rising as population, economic activity, climate change and agricultural irrigation grow. Therefore, worldwide resources of accessible water are decreasing due to overuse, effect of climate change or by anthropogenic pollution. The balance between demand (consumption) and supply (resource) is becoming unstable. More than 30 countries suffer from serious chronic water shortage, and groundwater is increasingly being used to cover the demand [1] which cannot be met by the other sources. When pumping surpasses the total recharge, a situation called groundwater mining is taking place and then the aquifer no longer sustainable. Rapid population expansion, intensive agriculture, reduction of precipitation, increase of evapotranspiration and tourism development can induce groundwater mining in a particular area. This can result in, reduction of aquifer storage, decrease of groundwater levels, land subsidence, depletion of groundwater quality and seawater intrusion in coastal aquifers [2].

When a coastal sandy aquifer is bounded by sea on either sides or lagoon in one side (island problem), it is vulnerable

*Address correspondence to this author at the Chemical and Environmental Systems Modelling Research Group, Institute of Fundamental Studies, Hantana Road, Kandy, Sri Lanka; Tel: +94812232002; Fax: +94 812232 131; E-mail: meththika@ifs.ac.lk or meththikavithanage@gmail.com to salt and brackish water intrusion or other types of contamination. This could be exacerbated by the high permeability of the sandy aquifer. Therefore, an assessment of the groundwater resources, in particular, these vulnerable aquifers, is very important for long term sustainability. However, assessments of groundwater resources are based on several assumptions and approximations. Although a number of techniques have been introduced to assess the available resources of the aquifers, i.e., safe yield, optimum yield, and groundwater sustainability [2], the most common approach is based on the concept of water balance. The evolution of the concept of Safe Yield has been reported by [3]. According to [4] safe yield is the rate at which groundwater can be withdrawn from an aquifer without causing an impact while Jacobs and [5] has defined it as a management goal that attempts to achieve and maintain long term balance between the annual amount of groundwater and the annual recharge. However, all of the above concepts are based on one foundation and that is the sustainability of the aquifer.

Groundwater is very important and is the only source of fresh water in the eastern coastal belt of Sri Lanka, especially in the sand stretches located between brackish water lagoons and the sea. It provides water for domestic use as well as for agriculture. However, the long term, sustainable yield of these aquifers is not known. The need for estimating the safe yield of the aquifer was triggered by the impact of the December 2004 tsunami as well as the expansion of population, intensification of agriculture in the region, and current climate change predictions. 
The safe yield of coastal aquifers may be further impacted by the projected changes in climate [6]. Increased surface temperature as well as the potential reduction in rainfall in the coast regions will reduce the net water supply available for domestic and agricultural uses further exacerbating the stresses caused by population expansion and associated land use changes. Future land use and water resources planning in these regions will need to account for both the existing water shortages during droughts as well as the potential reduction in available water supply associated with projected climate change.

\section{DESCRIPTION OF THE STUDY AREA}

\section{General Characteristics}

The east coast of Sri Lanka consists of elongated northsouth oriented coastal lagoons and land stretches bordered by ocean on the east and brackish lagoon on west. The average width of the stretch is approximately $2.0 \mathrm{~km}$ oriented in eastwest. The field site selected for this study is located at one of the largest lagoon areas, namely Batticaloa, in eastern Sri Lanka (Fig. 1), which was catastrophically damaged by the Indian Ocean tsunami in 2004.

The pilot study area selected for this study, Kirankulum, is located about $25 \mathrm{~km}$ south of Batticaloa (Fig. 1), one of the major towns in the region. The study transect is approximately located in $\mathrm{N}^{0} 36^{\prime} 03^{\prime \prime}$ and $\mathrm{E} 81^{\circ} 47^{\prime} 10^{\prime \prime}$ at the sea and in $\mathrm{N} 7^{\circ} 35^{\prime} 47^{\prime \prime}$ and $\mathrm{E} 81^{\circ} 45^{\prime} 58^{\prime \prime}$ at the lagoon side. The field site is uninhabited and sparsely vegetated by thorny shrubs with very few trees. The ground surface is almost flat and the elevation in the middle part between the sea and the lagoon is about 3 to 4 meters above the mean sea level (msl). Fresh groundwater at the site originates entirely from local rainfall-recharge and the available quantity for withdrawals
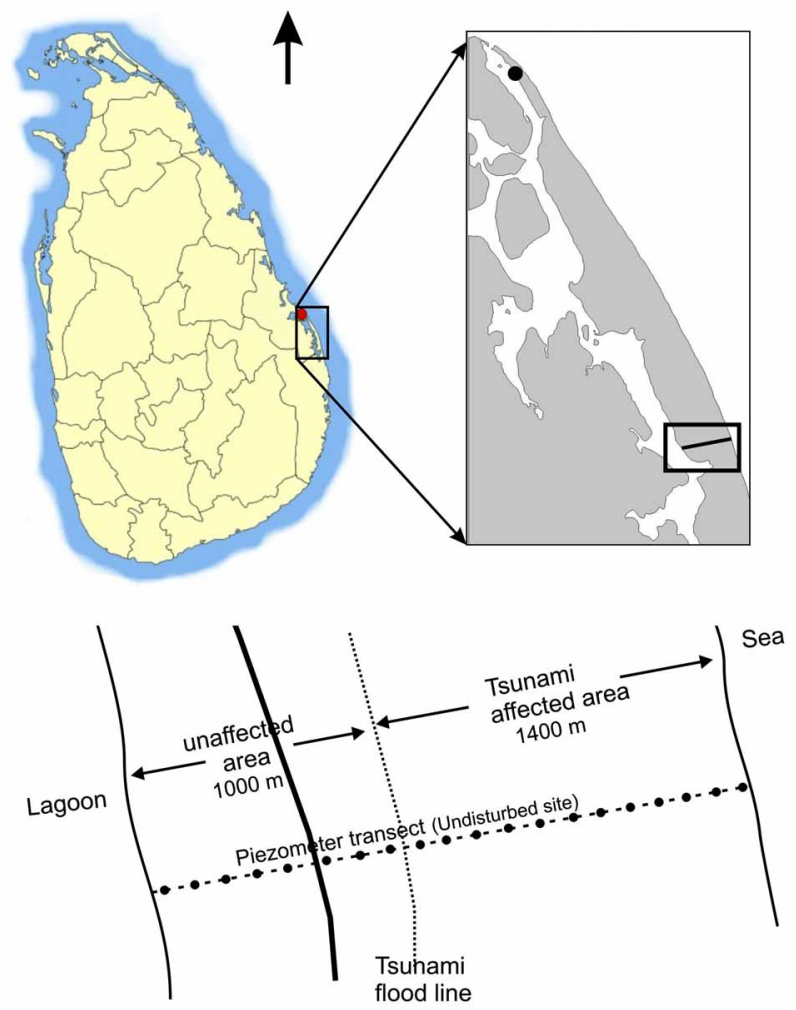

Fig. (1). Location map of the study area in between sea in the east and lagoon in the west. is thus limited. Particular pilot study area is undisturbed in terms of pumping. However a village area, located about 500 $m$ north of the study transect, consists of a cluster of small one-story houses and relatively small paved area sand it is the closest human settlement. This inhabited area consists of a total of 57 dug wells within an area of $0.5 \mathrm{~km}^{2}$ used by 113 families (500 people). These dug wells are used to pump water for domestic use as well as for small scale agriculture.

\section{Climate and Hydrology}

The study area belongs to the dry zone of Sri Lanka with an annual rainfall ranging from 1200 to $1900 \mathrm{~mm}$. Eighty percent of the annual rainfall falls intensively in the northeast monsoon period from November to February and during the inter monsoon periods from October to November and March to April [7]. As the ambient temperature is high year round $\left(38-33{ }^{0} \mathrm{C}\right)$ evaporation is estimated to be high around $30-50 \%$ of the precipitation [7]. Flooding is recorded in the area approximately once every year.

It is also important to consider future potential changes to the climate in our assessment on water resources availability. The latest climate change predictions for the year 2050 were reported for Sri Lanka based on IPCC SRES A2 and B2 scenarios [8] showed that the greatest reductions in wet season rainfall are in Batticaloa and it is predicted to be about $16 \%$ for A2 scenario and $12 \%$ for the B2 scenario [9]. Furthermore, during the wet season in Batticaloa, the average temperature increase has been predicted to be about $1.4{ }^{0} \mathrm{C}$ (for A2) and $1{ }^{0} \mathrm{C}$ (for B2), while the reference evapotranspiration increase has been predicted to be $1.3 \%$ (for A2) and $1.1 \%$ (for $\mathrm{B} 2$ ). The reductions in rainfall combined with higher temperatures will lead to higher irrigation requirements. The predicted wet season paddy irrigation requirements based on the baseline scenario (1961-1990) for 2050 were reported as $45 \%$ (for A2) and $15 \%$ (for B2) for Batticaloa [9].

\section{Land, Water Use and Urbanization}

The land use in the sand stretch is predominantly urban and semi-urban residencies, and agriculture. The agricultural lands are mainly used for growing paddy, vegetables and fruits. In some parts, flood irrigation is taking place for paddy cultivation. Those areas are underlain by clay and located mostly in the south western part of the sandy stretch. Other than paddy, onion, egg plants, ground nuts and chilies are grown in home gardens and small fields. Large area of this stretch is covered by a densely populated urban environment. This area is one of the areas of highest population density in Sri Lanka. The population increase in Batticaloa District has been recorded as 330,333 in 1981 to 486,447 in 2001 and the annual population increase from 2001 to 2006 is reported as 488,000 to 668,000 (Source: Department of Census and Statistics, Sri Lanka). The average annual growth rate of the population is given as $1.9 \%$ for the same district and the population density is about 186 inhabitants per $\mathrm{km}^{2}$ (Source: Department of Census and Statistics, Sri Lanka). However the population density is much higher in the townships in the region. Approximately $80 \%$ of the water demand in this area is considered for domestic use.

In town areas water supply is provided by the National Water Supply and Drainage Board of Sri Lanka. Large pro- 
duction wells (with an average depth of a production well of about 8-10 m) on this sandy stretch are the backbone of water supply. In the year 2004, the groundwater supply for the Batticaloa town is reported as $1450 \mathrm{~m}^{3}$ per day [10]. In addition, groundwater is pumped from the small private dug wells in almost every household. These dug wells have an average diameter of $1.3 \mathrm{~m}$ and an average depth of $3.2 \mathrm{~m}$. These wells are used in many of the coastal areas as individual or community wells for supplying potable water. They are designed to tap the shallow fresh groundwater zones in the coastal aquifers. Typical Sri Lankan coastal villages are densely populated and the well density is approximately 90 $125 \mathrm{~km}^{2}$ [11]. These wells are built using concrete cylinders in open excavations. Groundwater is also pumped extensively for agricultural applications. After the December 2004 tsunami, several new production wells and deep tube wells were constructed extensively throughout the sandy stretch by both government and non-governmental organizations without paying any attention to concepts of aquifer safe yield and sustainability.

Freshwater water availability during January to March is more than adequate due to high amount of rainfall by the northeastern monsoon. During January-March cropping season the water levels drops about one to two meters after pumping from large agricultural wells and they recover to the original level in about three to four hours time after pumping stops. In the dry season (October to February), the recovery takes only six to ten hours due to very high density of wells in the region [12]. Other than the domestic wells and agricultural wells, there are hand-pumped and mechanicallypumped shallow tube wells, which have been used for household and agricultural uses, and also occasionally for small industrial use. The number of shallow tube wells were 145 in the year of 2004 [10].

Some of the groundwater pumped for irrigation and domestic purposes are returned back to the aquifer and part will be lost by evapotranspiration. The return flow is estimated to be about $30 \%$ of the abstraction [13]. There is also evidence which suggest that the groundwater quality is declining in the agricultural areas due to extensive fertilizer application. As the sandy aquifer has high hydraulic conductivity, farmers use more fertilizer than what the crops need since the water is recharged rapidly. Consequently, the artificial recharge by irrigation is considered to be high.

\section{Geology and Hydrogeology of the Area}

Site specific geological data from drilling are available from the study area from previous studies [14]. Overall grain size distribution results showed 15 layers with some of them having noticeable differences in the hydraulic conductivity (K) values. The slug tests produced results higher $\left(6 \times 10^{-4}\right.$ to $3 \times 10^{-4} \mathrm{~m} / \mathrm{s}$ ) than the $\mathrm{K}$ values computed by the grain size distribution $\left(5 \times 10^{-4}\right.$ to $\left.8 \times 10^{-6} \mathrm{~m} / \mathrm{s}\right)$. This could be due to the variation in local heterogeneity. The effective permeability (k) for the field site is $3.3 \times 10^{-12} \mathrm{~m} / \mathrm{s}$.

The litho-stratigraphy in the pilot study site is a mixture of several layers sometimes with slight different K (Fig. 2). First, medium sand layer of approximately $7 \mathrm{~m}$ depth and second, sand with a small fraction of clay and shell fragments were found. Clay-mixed sandy layer of about 3-5 $\mathrm{m}$ in thickness is found below the sand layer, which is then followed by a thin coarse sand layer of about $2 \mathrm{~m}$ in thickness. Thereafter, few thin medium sand layers alternatively mixed with silt mixed fine sand were found. Wickramaratne (2004) [15] reported that the bed rock is found at a depth of about $15-25 \mathrm{~m}$ in a field site about $15 \mathrm{~km}$ north of the pilot field site. The bed rock depth in the pilot field site was obtained from the Transient Electro Magnetism measurements [16].

As discussed earlier, the aquifer system is highly productive in terms of water abstraction and highly vulnerable for pollution. The freshwater lens developed by the rainfall recharge provides limited amount of water due to shallow depth and rapid discharge of freshwater into the sea and lagoon. A study by Nadarajah (2002) [12] showed that the upper region of the aquifer consists of sands with various hydraulic conductivities ranging from $1.43 \times 10^{-4}$ to $8.79 \times 10^{-5}$ $\mathrm{m} / \mathrm{s}$ and the average initial infiltration rate has been estimated to be about $60 \mathrm{~mm} / \mathrm{hr}$ while the stabilized infiltration rate is $32 \mathrm{~mm} / \mathrm{hr}$. Furthermore he reported that the pumping for agriculture was around $0.3 \mathrm{~m}^{3} /$ minute with average pumping period of 6 hours for 120 days per year. The most pumping occurs from May to September in the dry season.

Only very few studies have been carried out to investigate the hydrogeology of the sandy aquifers in the east coast of Sri Lanka. One of the major reasons for the lack of studies is the long standing civil war situation in the northern and eastern parts of the country for more than 25 years. Few unpublished literature are available with regard to hydrogeology and groundwater quality in the region.

\section{Groundwater Quality}

The quality of groundwater is determined by two major processes, i.e. water-rock interaction and human activities such as agriculture, waste dumping sites, septic tanks, domestic and industrial effluents [17]. The study area does not have municipal waste water collection sites or major landfill sites and therefore the groundwater contamination is mainly due to agriculture, septic tanks and domestic effluents. Some

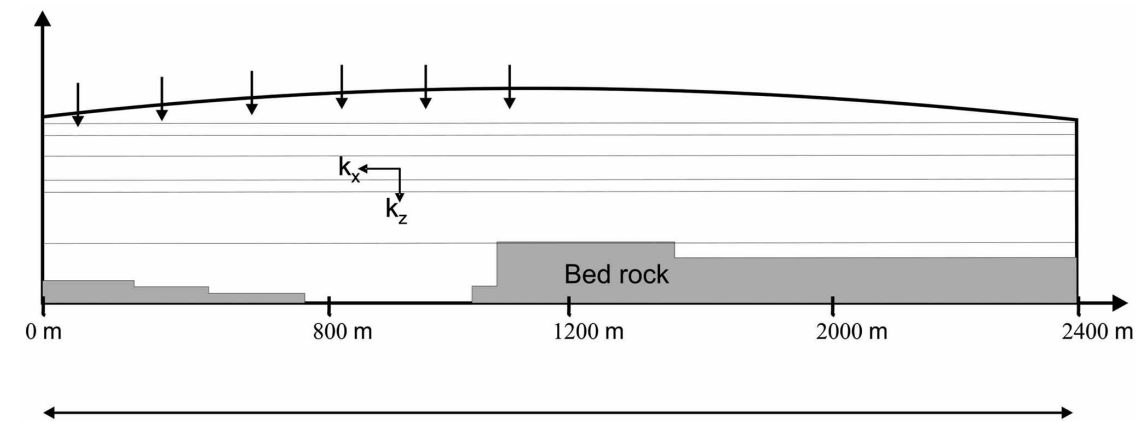

Fig. (2). Schematic view of the aquifer in the pilot field site. 
of the previously unpublished literature has provided data on the water quality in the shallow groundwater aquifers in eastern Sri Lanka [15, 18-21]. Few of them reported relatively high electrical conductivity (EC) levels especially in agricultural wells. According to [7], only three agricultural wells out of 25 from the Trincomalee District (located on the north east coast of the country) had EC values less than 500 $\mu \mathrm{S} / \mathrm{cm}$; most were above $1000 \mu \mathrm{S} / \mathrm{cm}$ while some others were higher than $2000 \mu \mathrm{S} / \mathrm{cm}$ during the dry season. Similar results were reported by [20]. However, as agricultural wells are larger in size, and pumped more heavily to supply water for irrigation, they may not be representative of the domestic wells. It has been shown that, in general, agricultural wells have higher salinity levels than domestic dug wells [22] and [21]. In the study by Wickramaratne (2004) [15], EC levels below $700 \mu \mathrm{S} / \mathrm{cm}$ were reported for shallow (< $12 \mathrm{~m}$ deep) tube wells which are used for domestic water supply. The seasonal fluctuations of EC observed can be explained by salt build-up in the vadose zone due to strong evaporation processes during the dry season [15]. This salt accumulation is then flushed out into the aquifer during the rainy season. Well water may also become more salty in the dry season due to evaporation directly from the open water surface. Calcium and magnesium concentrations of well water have been recorded between $250-1450 \mathrm{mg} / \mathrm{L}$ and $30-250 \mathrm{mg} / \mathrm{L}$, respectively [18]. Vaheesar (2002) [19] has reported that nitrate concentration in most areas in the Batticaloa District is above the WHO standard limit ( $45 \mathrm{mg} / \mathrm{L})$. However, the nitrate concentrations in agrowells reported from the [20] showed a maximum concentration of $35 \mathrm{mg} / \mathrm{L}$. The water quality data obtained from the field site, plotted in a tri-linear piper diagram, demonstrated that the predominant water type of the aquifer is $\mathrm{Ca}-\mathrm{HCO} 3$ type according to the hydrogeochemical classification system.

Groundwater levels in the particular sand stretch are transient based on rainfall at a particular time. Observations from [15] showed that the ground water table varies from 0.5 to $3.0 \mathrm{~m}$. The ground water levels in the agro wells (large wells that are created to pump water continuously for cultivation) in a site about $15 \mathrm{~km}$ south of Kirankulum were reported by [21] and the lowest water table there was recorded as $2.5 \mathrm{~m}$ below the surface in June and the highest water table was reported below $1.5 \mathrm{~m}$ in February. During the monsoon rainy season from November to February, a gradual increase in the water table levels was observed in response to infiltrating rainwater, reaching the highest levels during the month of January and then decreasing in the following months as recharge diminished [14]. The depths of most of the wells are in between three to six meters from the land surface. During the peak of the rainy season, the water level reaches the ground level and during dry season water level drops by about two to four meters and the wells never get dried up. As the water table rises, a groundwater mound is creating, giving rise to an overall bi-directional flow of groundwater within the strip of land.

\section{SYNTHETIC MODELING STUDY}

The Heat and Solute Transport code HST3D [23] was used to evaluate the groundwater balance and safe yield of the aquifer with regard to the saltwater intrusion and upconing. This code is capable of simulating density driven flow and transport in a 2D/3D saturated groundwater flow system including saltwater intrusion, leachate flow from landfills etc. HST3D solves three basic equations; 1) the saturated groundwater flow equation, 2) the heat transport equation and 3 ) the solute transport equation [23].

The discretization of the simulation domain in HST3D was implemented using a point-distributed grid using Cartesian coordinate system. Backward differencing method was used for both spatial and temporal discretization although it introduces some numerical dispersion in the solution. The magnitude of the numerical dispersion and the instabilities in the backward differencing scheme was diminished by using an irregular, but a fine mesh and small time stepping.

Two prescribed pressure boundaries and a top flux boundary were considered as the hydrologic boundaries in this model domain (Fig. 2). Two pressure boundaries in left and right sides of the model domain represent the sea and the lagoon with saltwater and brackish water respectively. In the case investigated, a more general domain was selected for this synthetic case to study the effects of pumping on water quality of a generalized aquifer with intrusion from sea and lagoon. Therefore more general model, a rectangular domain consisting of flat bed rock with an average depth of $22 \mathrm{~m}$ from msl, was selected to represent the aquifer here in. However, the groundwater flow part of the model was calibrated for an effective $\mathrm{k}$ value with a domain represent a field transect with 20 piezometers, which is located $500 \mathrm{~m}$ away from the pilot study site [14]. This calibrated $\mathrm{k}$ was applied for this synthetic study. Prescribed flux boundary is defined on the top of the model domain with recharge calculated for the field conditions using Penman-Monteith Equation [24] for ET calculations and HYDRUS1D [25] to simulate the unsaturated zone. The bottom of the model domain was assumed to be a no-flow boundary.

The design for the rectangular mesh used in the simulations consisted of 21306 nodes, 201 in $\mathrm{X}$ direction, 2 in $\mathrm{Y}$ direction and 53 in $\mathrm{Z}$ direction with a discretization of $10 \mathrm{~m}$ and $0.5 \mathrm{~m}$ size cells in $\mathrm{X}$ and $\mathrm{Z}$ directions respectively. It has been suggested that the aspect ratio of cells should kept to one as close as possible, and the violations of this criteria may cause oscillations in the solution [26]. However, this aspect ratio did not show any effect on our simulation results and this was confirmed by ensuring that there were no overshooting and undershooting in mass fraction results. Fifteen wells were established in the model domain at depths ranging from $-4 \mathrm{~m}$ to $2 \mathrm{~m}$ from $\mathrm{msl}$ and they were located from 600 to $1650 \mathrm{~m}$ from the sea boundary with $75 \mathrm{~m}$ distance between wells. The above distances and well numbers were chosen based on the data obtained from the pilot field site. The wells were located up to $3 \mathrm{~m}$ below msl. Initial conditions were defined at the start of the simulation from a steady state simulation. As this is a transient problem, simulating steady state conditions at the beginning, resulted a massbalanced starting point. Average recharge of $1.57 \times 10^{-3} \mathrm{~m} / \mathrm{d}$ obtained from HYDRUS 1D simulation was used for the steady state simulation. Hydrostatic conditions in the two boundaries were defined at both sides as known elevations (zero msl). Since the system is sensitive to the initial conditions, average, and dry years were repeated for several cycles to reduce the effect of the initial condition on the transient portion of the simulation which used a general pattern corresponding to average and dry years. Intrinsic permeability, 
porosity, density, viscosity, recharge, molecular diffusion coefficient, longitudinal and transverse dispersivities are considered as the input data for the model are reported in Table 1.

\section{Groundwater Discharge}

The total amount of groundwater withdrawn from this aquifer is from artificial withdrawal by means of dug wells and agro wells for domestic and agricultural purposes respectively and the natural discharges, which is by evapotranspiration losses and groundwater discharge to sea and lagoon.

\section{Scenario Simulations}

The effect of groundwater use on the saltwater intrusion is simulated in 2D. Two main scenarios corresponding to present water use and future water use based on the population were used for the simulations. Two dimensional model simulations were carried out with an initial steady state condition with an average recharge of $1.57 \times 10^{-3} \mathrm{~m} / \mathrm{d}$ to observe the effect of water use for domestic purposes in the village area when the discharge for domestic uses for the present day scenario was estimated as $5 \times 10^{-4} \mathrm{~m}^{3} / \mathrm{m}^{2}$ and $1.1 \times 10^{-3}$ $\mathrm{m}^{3} / \mathrm{m}^{2}$ for the future scenario. These two main scenarios were simulated to obtain a steady condition for the average and dry years respectively. The average and dry years were selected based on daily rainfall and simulated daily recharge values for the 10 years of meteorological data. The average abstraction per well was calculated as $0.093 \mathrm{~m}^{3} /$ day based on field data. Future scenario was based on the population projections in 2050 and therefore pumpage increased to $0.2 \mathrm{~m}^{3}$ per well per day for the same area where it is equal to 1.1 $\mathrm{x} 10^{-3} \mathrm{~m}^{3} / \mathrm{m}^{2}$. Several different configurations were simulated by changing the pumping, recharge, intrinsic permeability and aquifer depth which are shown in Fig. (3). Other than those are shown in Fig. (3), one simulation was carried out with no pumping to observe the effect of natural recharge on the system.

\section{Groundwater Recharge for HST3D}

This landscape does not contain any surface water drainage features such as rivers or canals and therefore the only hydrologic variables of interest to the recharge in the region are precipitation and return flow from domestic and irrigation water use. The climate data obtained for this study (1978-1987 selected based on the most continuous period of

Table 1. Model Input Parameters and Variables

\begin{tabular}{|c|c|c|c|}
\hline Model input parameters & Value & Units & Data source \\
\hline Intrinsic permeability & $1.96 \times 10^{-12}$ & $\mathrm{~m}^{2}$ & Estimated from Hydraulic Conductivity (grain size distributions) and sensitivity tests \\
\hline Porosity & 30 & $\%$ & Published literature and sensitivity tests \\
\hline Density & & $\mathrm{kg} / \mathrm{m}^{3}$ & Published literature \\
\hline Freshwater & 998.23 & & \\
\hline Brackishwater & 1010.0 & & \\
\hline Saltwater & 1025.0 & & \\
\hline Viscosity & 0.001 & $\mathrm{~kg} / \mathrm{ms}$ & Published literature \\
\hline Diffusivity & $1 \times 10^{-9}$ & $\mathrm{~m}^{2} / \mathrm{s}$ & Published literature \\
\hline Dispersivities & & & \\
\hline$\alpha_{\mathrm{L}}$ & 1.0 & $\mathrm{~m}$ & Published literature \\
\hline$\alpha_{\mathrm{T}}$ & 0.1 & & \\
\hline Recharge & varies & $\mathrm{m} / \mathrm{d}$ & Estimated from FAO Penman-Monteith equation and HYDRUS 1D simulations \\
\hline
\end{tabular}

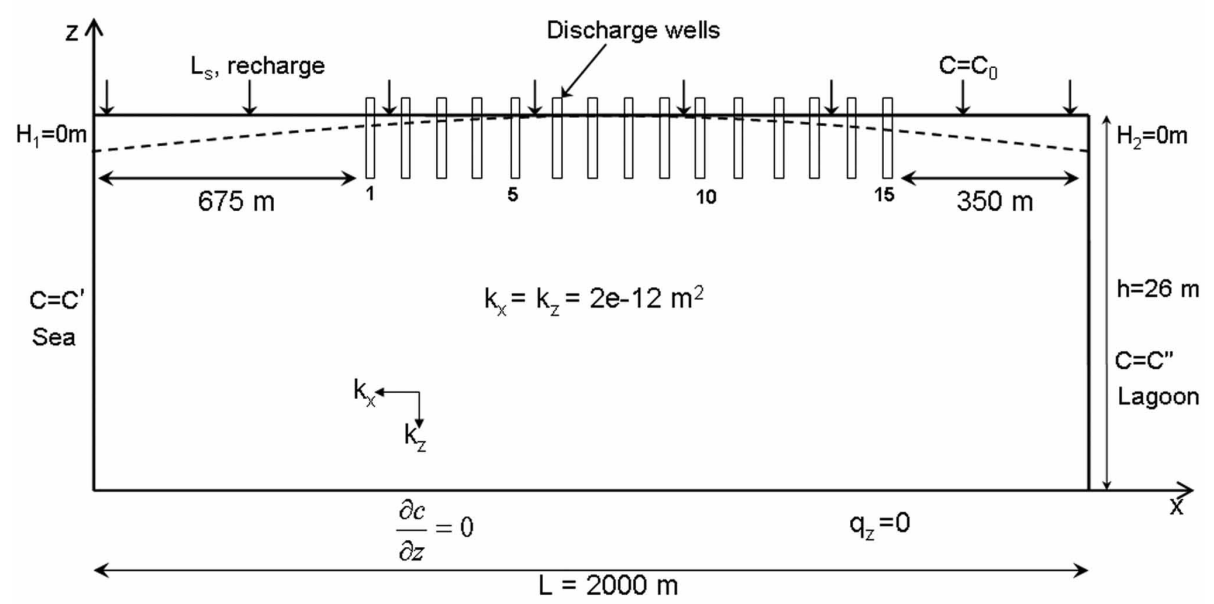

Fig. (3). Schematic representation of the model domain used in HST3D simulations. 
all meteorological data for the calculation of ET) was used to obtain an average and dry year. The average annual rainfall was $1430 \mathrm{~mm}$ for the period.

\section{Estimation of Potential Evapotranspiration}

Evapotranspiration is one of the major hydrologic parameter that is needed for accounting surface and subsurface water resources. Reference ET was calculated with the FAOPenman-Monteith equation for ET with a temperature based estimation of solar radiation [24]. The Penman-Monteith Method (1) requires measured parameters of average, maximum and minimum air temperature, vapour pressure, sunshine hours and wind speed. The estimation of the reference crop evapotranspiration using the Penman-Monteith method in an Excel spreadhseet. The main parameters used as input into the spreadsheet were maximum temperature (Tmax), minimum temperature (Tmin), vapour pressure and wind speed obtained from the Batticaloa meteorological station. Daily measurements were input into the spreadsheet for a 10year period.

\section{Recharge Due to Rainfall and Return Flow}

Groundwater recharge in the study area mainly occurs as percolation of rainwater, return flow of water applied for irrigation and domestic uses. Almost all the rainfall precipitated on the ground is recharged into the aquifer in the early period of rainy season. Recharge varies ranged from $40-80 \%$ of monthly precipitation during the monsoon period. In HYDRUS 1D, water flow and root water uptake options were combined together with van Genuchten-Mualem soil hydraulic model and to simulate the daily recharge for the baseline scenario period (1978 to 1987). The calculated potential evapotranspiration using Penman-Monteith equation was used in HYDRUS 1D to simulate the recharge. The resulting daily recharge values were averaged to obtain a mean daily value for the each month and were used in HST3D (Table 2). It has been estimated that return flow from irrigation and domestic water use is $30 \%$ of the abstraction. This amount was subtracted from the abstractions in HST3D simulations. Fourteen percent of wet season recharge reduction was used for the future based average year and dry year simulations based on [9].

\section{RESULTS AND DISCUSSION}

Estimated reference evapotranspiration (ETr) ranged from 0 to $5 \mathrm{~mm} / \mathrm{d}$ and average ETr was $4.0 \mathrm{~mm} / \mathrm{d}$. The average reference evapotranspiration was multiplied by the crop coefficient resulting in Potential evapotranspiration for the particular crops in the region. The average monthly rainfall and potential evapotranspiration is $114 \mathrm{~mm} 1 \mathrm{~mm}$ respectively. The term, average hydrological year is used for the year with an average recharge, while the term dry hydrological year is for the year with the recharge corresponding to a dry year (Table 2). Each average and dry year simulations consisted of four scenarios (Fig. 3).

\section{Average Year Carrying Capacity}

Simulation result from no-pumping scenario for the average year showed that the saltwater intrusion and brackish water intrusion from both sides are very limited. During dry season of an average hydrological year, the saltwater intrusion is around $250 \mathrm{~m}$ from the sea at the aquifer bottom (22 $\mathrm{m}$ from msl) while the brackish water intrusion is less than $225 \mathrm{~m}$ inland (Fig. 4). However, with the present pumping rate, the average year shows a much broader intrusions from both sides, twice as that for no-pumping (Fig. 4) case which is more prominent during the driest month. Although the intrusion is wide, it does not show any effect on wells and therefore the water supply wells are able to provide adequate fresh, good quality drinking water. The contour line of 0.056 mass fraction shows the freshwater with an electrical conductivity of $3000 \mu \mathrm{S} / \mathrm{cm}$, which is considered salinized well water (not suitable either drinking or agriculture). The water table variation during this year is approximately $3 \mathrm{~m}$. Changes in intrinsic permeability and bed rock depth were performed only for the average hydrological year with present pumping rate with the present recharge values. With the increase of the intrinsic permeability value by twice the intrusion observed is same in the present pumping and recharge scenario (Figure not shown). Similarly, no difference was detected from the simulation with changing bedrock depth to $17 \mathrm{~m}$ below msl. Same simulations were performed with distributed wells from 300 to $1700 \mathrm{~m}$ from the sea with a $100 \mathrm{~m}$ distance in between. However, they did not show any effect on wells even in the driest period of the year. Even though the intrusion was broader, it was less than that of present pumping of the average year with present recharge.

The second set of simulations provides results for the scenario of present day pumping rate $\left(0.093 \mathrm{~m}^{3} / \mathrm{d}\right)$ with the recharge predicted for 2050 (14\% reduction due to climate change). It showed similar results (not shown) to the first scenario simulation present pumping and recharge. The aquifer is able to provide drinking quality water, if the wells are pumped at the present pumping rate even though the recharge for wet season has been reduced by $14 \%$. However, the salt and brackish water intrusion has moved up to 700 and $500 \mathrm{~m}$ inland from both boundaries respectively. Third scenario for the average hydrological year was performed with future pumping rate and with the present, average year recharge values. With a pumping rate of $1.1 \times 10^{-3} \mathrm{~m}^{3} / \mathrm{m}^{2}$ aquifer was becoming contaminated by brackish water from the lagoon side. Wells are located close to the lagoon than to

Table 2. Daily Recharge Values Obtained from the HYDRUS 1D Simulations

\begin{tabular}{|c|c|c|c|c|c|c|c|c|c|c|c|c|}
\hline Year & \multicolumn{12}{|c|}{ Recharge, $\mathbf{m m} / \mathbf{d}$} \\
\hline Dry & 2.15 & 1.15 & 2.15 & 2.09 & 2.17 & 0.73 & 1.97 & -0.60 & -3.78 & -9.06 & -2.88 & -8.46 \\
\hline
\end{tabular}

Note: positive values represent the upward movement of water due to capillary effect and evapotranspiration and negative values represent the recharge to groundwater. 


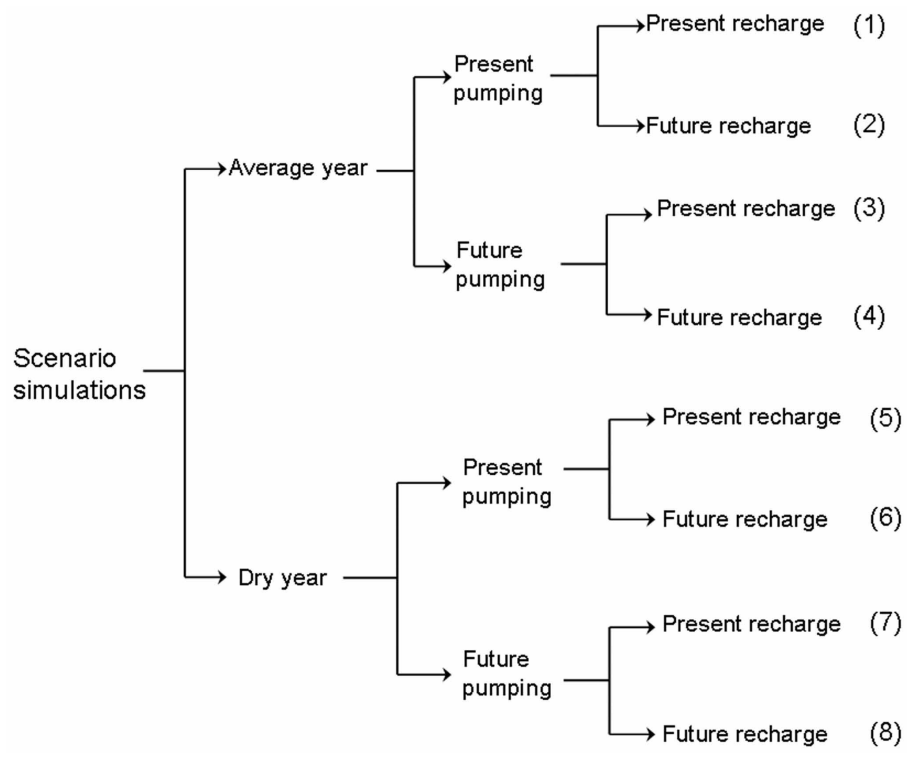

Fig. (4). Tree diagram showing different simulation scenarios.

the sea in this particular sand stretch. Therefore the wells close to the lagoon can get contaminated from brackish water from the lagoon quicker. As shown in Fig. (5a) and (5b), closest well to the lagoon (at $1650 \mathrm{~m}$ from sea) is contaminated and the very next one is in the limit of $3000 \mu \mathrm{S} / \mathrm{cm}$ (0.056 in mass fraction contours) indicating the wells inland are in danger of getting contaminated by the saltwater. At this point, the pumping should be stopped or reduced to a certain level to maintain the aquifer safe yield. However, the salinity levels showed a seasonal behavior based on wet and dry season. The status of the aquifer for every scenario is shown in Table 3.

Fourth scenario was carried out with future pumping rate $\left(1.1 \times 10^{-3} \mathrm{~m}^{3} / \mathrm{m}^{2}\right)$ calculated according to the population projections for 2050 and future recharge values calculated based on the findings of [9]. The freshwater volume in the aquifer has been reduced significantly due to intrusion of the salt and brackish water front (Fig. 6a). Six wells out of fifteen is already contaminated (Fig. 6b) and have Electrical conductivity value of $>3000 \mu \mathrm{S} / \mathrm{cm}$ indicating non-drinkable water. Therefore, the aquifer is no longer sustainable with this

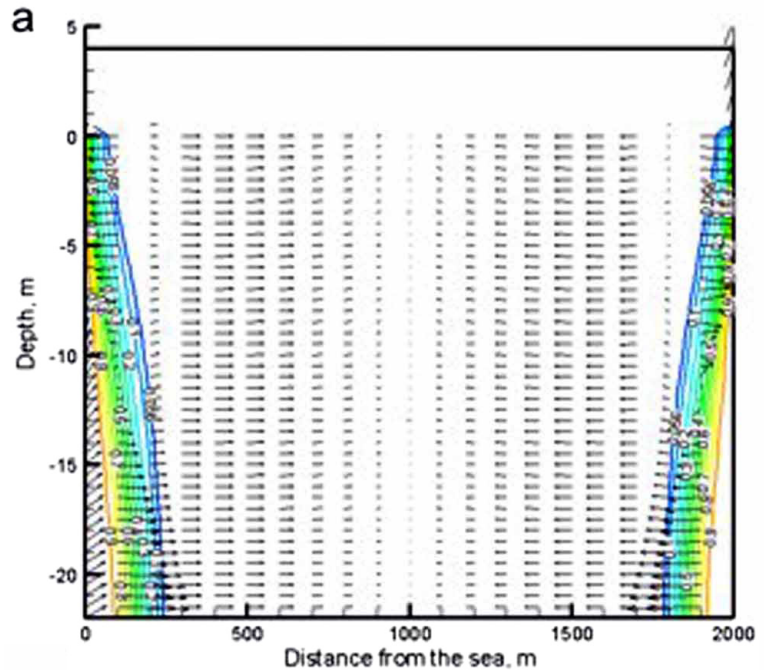

situation. When the recharge is reduced by $14 \%$ the maximum pumping should be less than the present day pumping rate, $5 \times 10^{-4} \mathrm{~m}^{3} / \mathrm{m}^{2}$ to obtain clean drinking water.

\section{Dry Year Carrying Capacity}

Similar to the average year simulations, four different scenarios were performed for the dry hydrological year. First simulation was with present day pumping rate and the present recharge (Table 2). The results showed that the water quality of the wells is not affected by salinity either from sea or lagoon. However, the intrusion was bit more towards inland compared to that of average year (not shown). Therefore, under this circumstance, the pumping does not affect the aquifer properties and keeps the aquifer under its safe yield. Similar results were obtained for the second scenario for the dry year. However, if there are wells close to the sea and lagoon around $300 \mathrm{~m}$ from the sea and lagoon respectively, they are susceptible to contamination by intrusion from both sides even though these dug wells are very shallow. Therefore it is important to maintain the shallow depths of wells as well as same distance from the two boundaries.

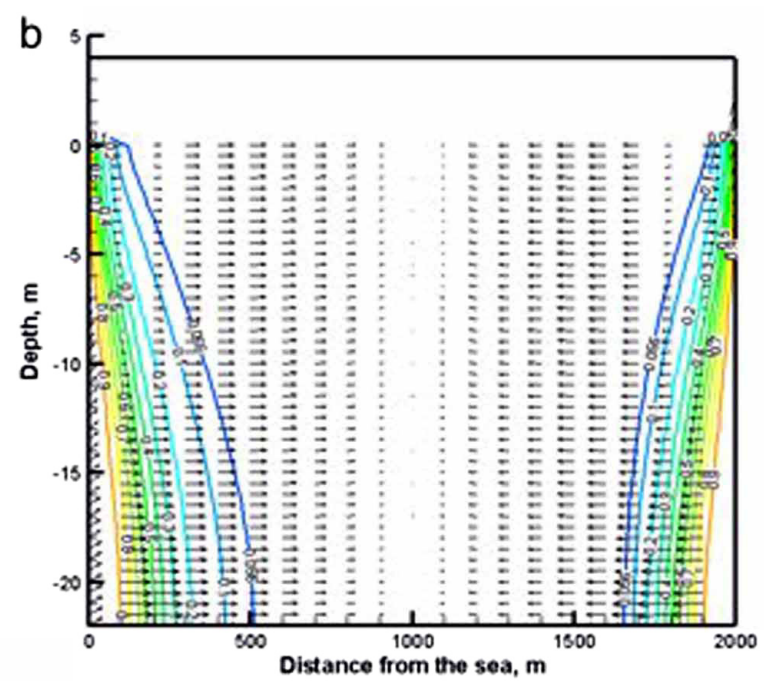

Fig. (5). The intrusion from sea (left) and lagoon (right) in two simulations for the driest period of the average year with present recharge. a) without pumping and b) with present rate of pumping. Mass fraction contours are shown with velocities (arrows). 
Table 3. Matrix Showing the Sustainable, Vulnerable and Endangered Status of the Aquifer Based on the Scenario Simulations

\begin{tabular}{|c|c|c|c|c|c|}
\hline Main Scenario & Sub Scenario & Present Recharge & Future Recharge & Bed Rock Depth, m & Higher Permeability \\
\hline \hline Average & Present pumping & X & X & X \\
\hline & Future pumping & X & X & -- \\
\hline Dry & Present pumping & X & X & -- \\
\hline & Future pumping & X & X & -- \\
\hline
\end{tabular}

Note: green: sustainable, yellow: vulnerable, red: endangered and --: no simulation performed
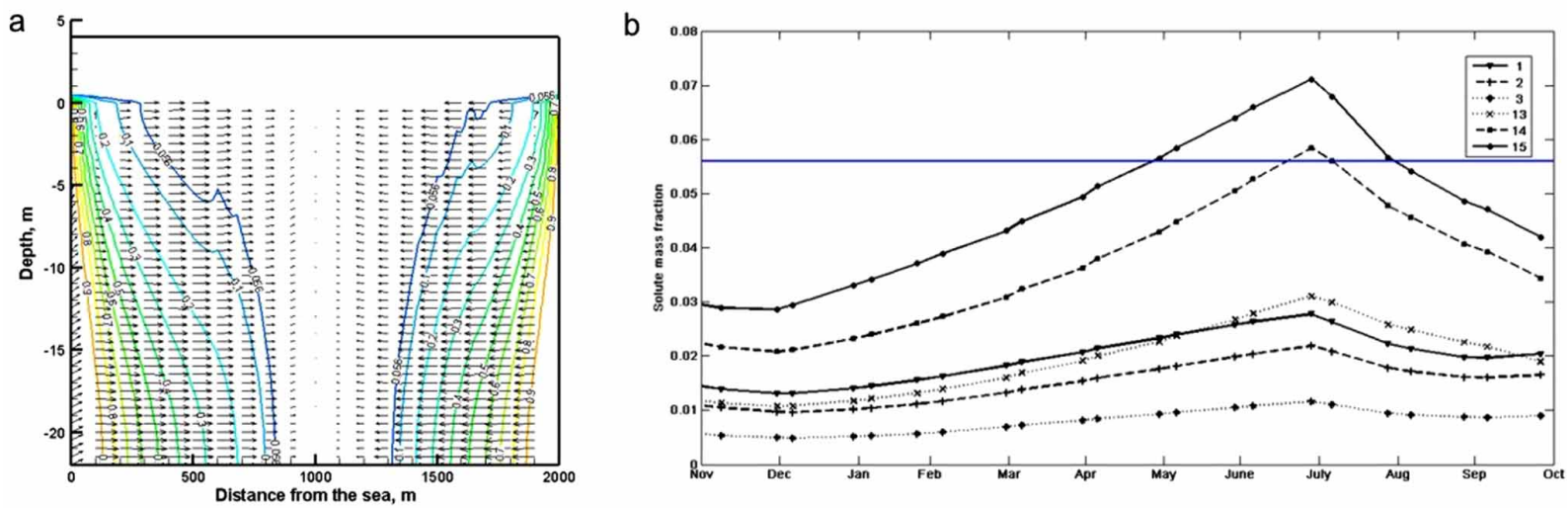

Fig. (6). The intrusion (a) and the contamination of wells (b) in the average year future pumping, present recharge scenario. The horizontal line on figure $b$ represents limit of $2000 \mu \mathrm{S} / \mathrm{cm}$. Well number 1, 2 and 3 are close to the sea while 13, 14 and 15 are close to the lagoon.

There should be at least $500 \mathrm{~m}$ distance from sea and lagoon to the first well to obtain a sustainable pumping from the wells in the driest part of a dry year.

Dry year scenarios for the future do not predict sustainable aquifer condition. Simulation with predicted future pumping and present dry year recharge shows the freshwater volume has reduced much more than the same simulation for the average year. Seven wells would be contaminated and have EC values higher than the limit of $3000 \mu \mathrm{S} / \mathrm{cm}$ (Fig. 7a). Very high EC levels were observable. Some wells showed EC values exceeding $5000 \mu \mathrm{S} / \mathrm{cm}$. The fourth scenario of the dry year is better than the third scenario, however, there are three wells affected by high salinity levels (Fig. 7b) in the driest part of the dry year scenario. Results show the dry year scenarios with future pumping do not demonstrate a sustainable aquifer condition (Figs. 8-10).

\section{Safe Yield to Sustainability}

When the urban water use is considered, this aquifer is under sustainable pumping conditions at the moment. However, predicted future pumping rate demonstrate aquifer is no longer be under sustainable conditions. Drinking quality water could be pumped still in the middle part of the aquifer at future pumping scenarios but the wells at the sides are contaminated with saline water. Future pumping with the average hydrological year recharge exhibits the alarming condition on wells getting contaminated. Therefore, future pumping conditions exceed the carrying capacity of the aquifer. Shallow wells can be an alternative for the aquifer getting contaminated. A long term sustainable strategy is to locate shallow wells (less than $3 \mathrm{~m}$ from $\mathrm{msl}$ ) in an $800 \mathrm{~m}$ wide strip centered in the areas between lagoon and sea.

Modeling results indicate that the current pumping will not affect the aquifer sustainability either with a dry year

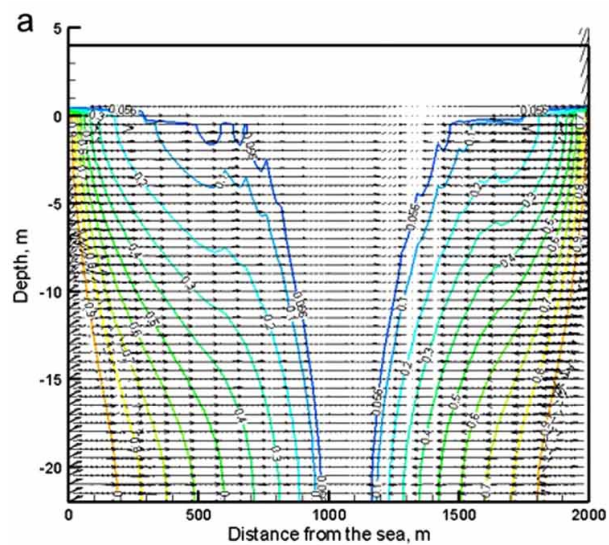

b

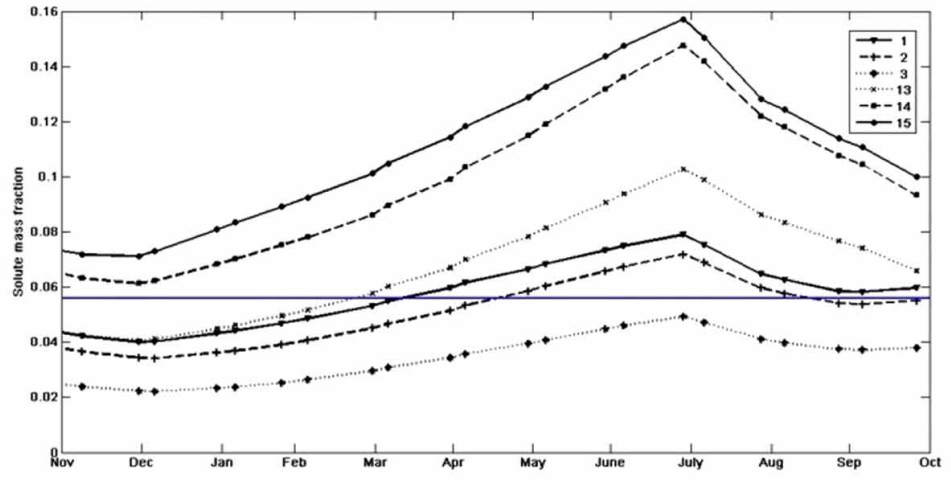

Fig. (7). The intrusion (a) and the contamination of wells (b) in the average year future pumping, present recharge scenario. The horizontal line on figure b represents limit of $2000 \mu \mathrm{S} / \mathrm{cm}$. Well number 1, 2 and 3 are close to the sea while 13,14 and 15 are close to the lagoon. 

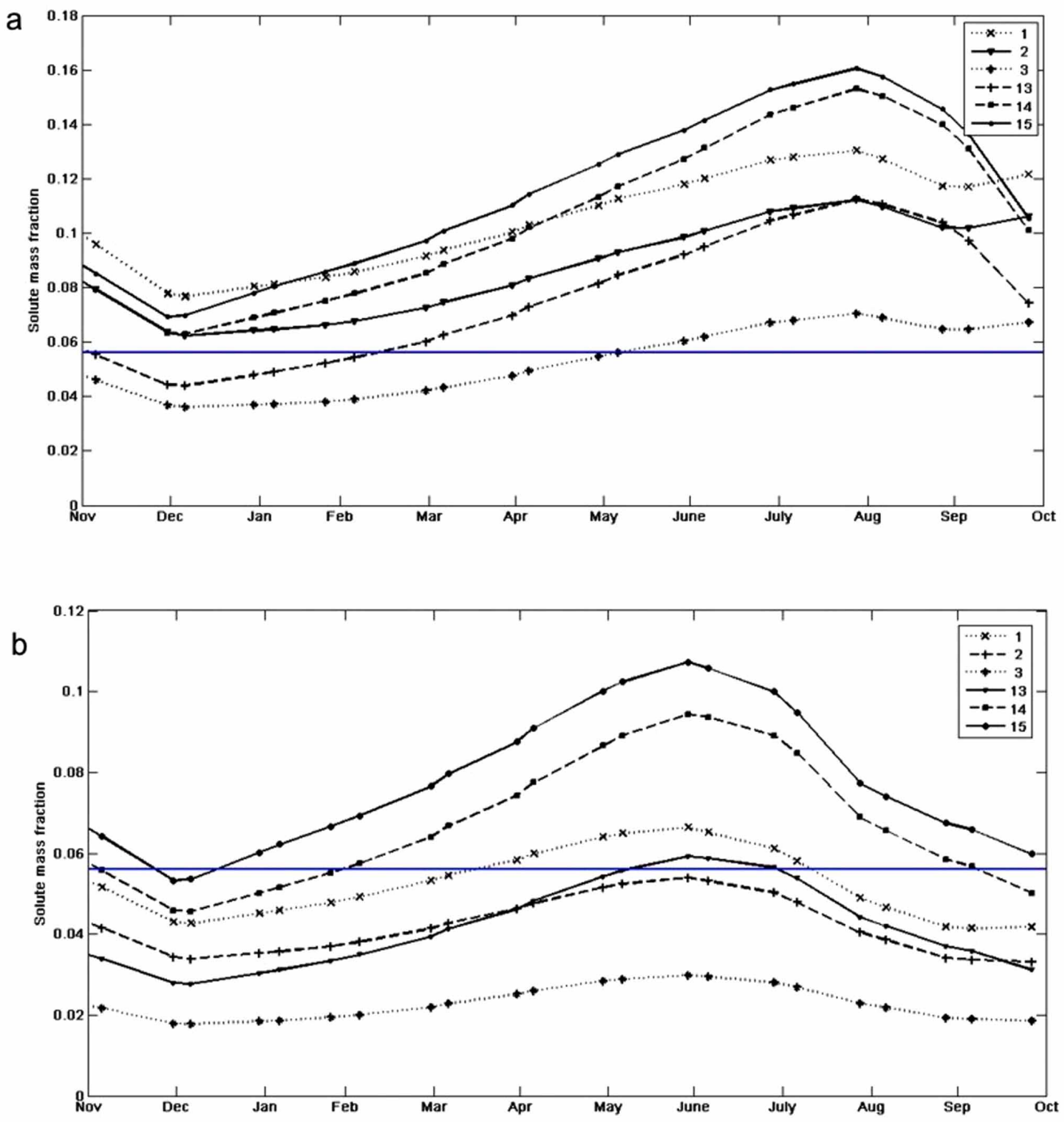

Fig. (8). Wells that are affected from the salinity under dry year condition. a) Predicted future pumping with present dry year recharge, and b) Predicted future pumping with reduced recharge (future recharge) based on climate predictions. Horizontal line represents limit of 2000 $\mu \mathrm{S} / \mathrm{cm}$.

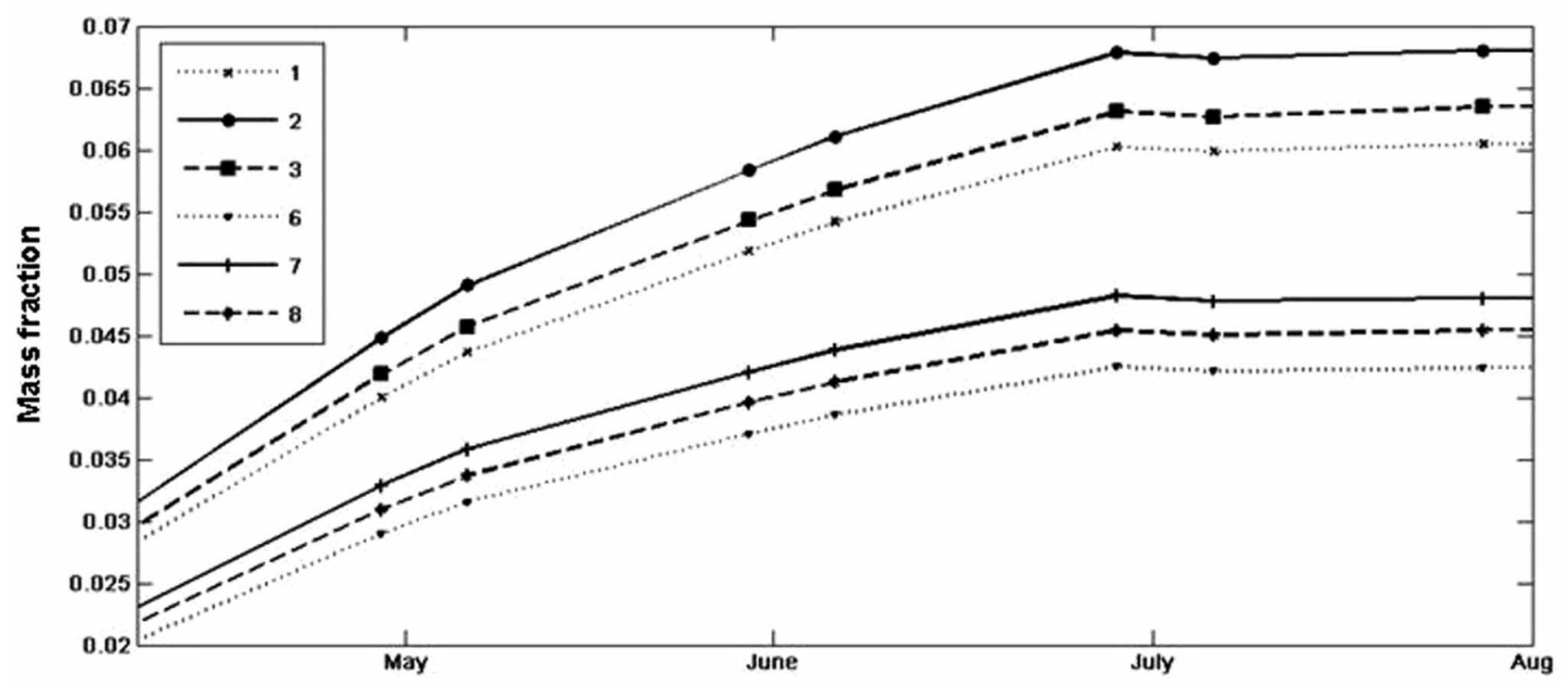

Fig. (9). The well salinity of the driest part of the average hydrological year from the agricultural pumping in scattered well field. Well number 1,2 and 3 are close to the sea while 6,7 and 8 are close to the lagoon. 


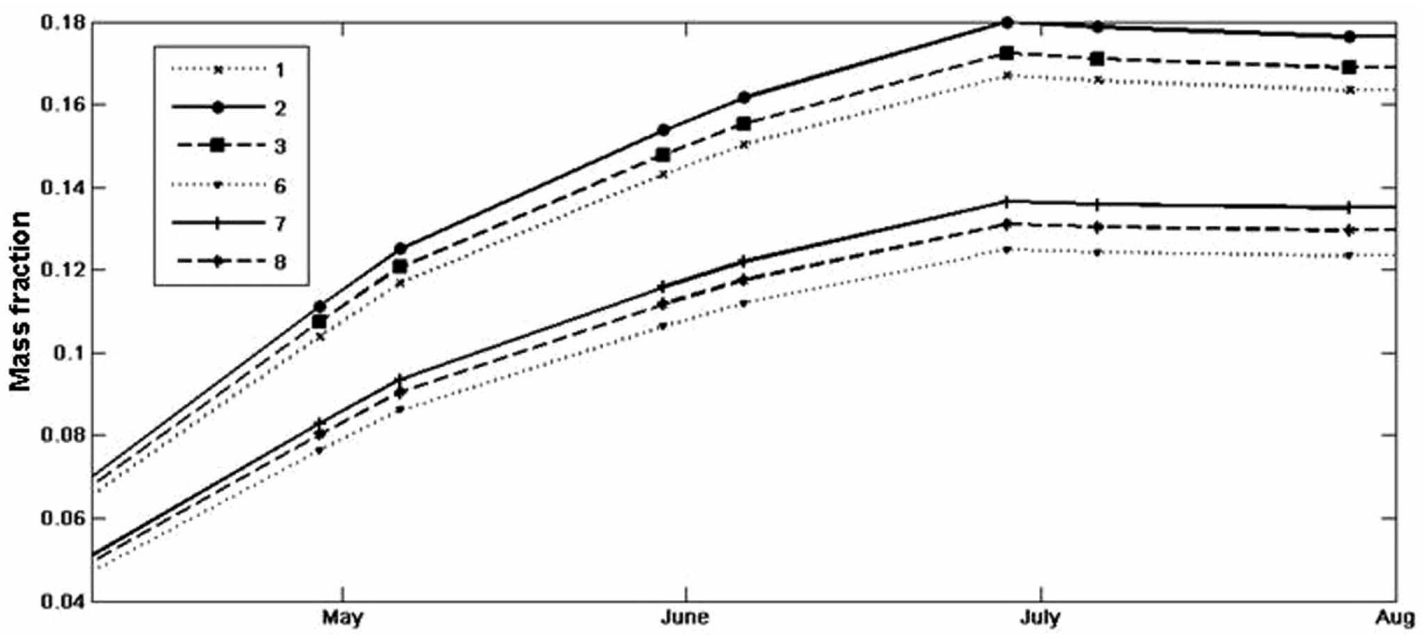

Fig. (10). The well salinity of the driest part of the average hydrological year from the agricultural pumping in distributed well field. Well number 1,2 and 3 are close to the sea while 6,7 and 8 are close to the lagoon.

recharge or with a reduced recharge by $14 \%$. If the average recharge continues, the safe yield of the aquifer or the maximum pumping rate for a sustainable condition is less than the future pumping rate, $1.1 \times 10^{-3} \mathrm{~m}^{3} / \mathrm{m}^{2}$. In both average and dry year cases future pumping made the aquifer to be endangered by saline intrusion (Table 3 ). Therefore, the carrying capacity of the aquifer resides with the present day pumping rate for both average year and dry year. The safe yield of the aquifer from domestic pumping is estimated as $5 \times 10^{-4} \mathrm{~m}^{3} / \mathrm{m}^{2}$ with a return flow of $30 \%$ of the abstraction.

Agricultural water use at the moment does not show any effect on the contamination of the aquifer if the wells lie outside $500 \mathrm{~m}$ region from the boundaries. If not the pumpage from the wells within $500 \mathrm{~m}$ should have low abstraction, $50 \%$ of normal agricultural pumping. Therefore the safe yield of the aquifer for agriculture can be estimated as 3240 $\mathrm{m}^{3} / \mathrm{km}^{2}$ per day with $30 \%$ as return flow however with wells inside at least $750 \mathrm{~m}$ from the boundaries.

Groundwater balance was obtained (Table 4) from the model for the average and dry scenarios. It shows that the volume pumping out is very close to the volume recharge during the dry year however since the return flow is high still the aquifer is in sustainable condition.

\section{CONCLUSIONS}

The eastern coastal belt is characterized by ongoing urbanization and intensive agriculture. Groundwater is the only source of water for this area since the sand stretch demarcated by sea and lagoon. Modeling of the carrying capacity of this aquifer was carried out using HST3D based on observations and data obtained from a pilot field area. The renewable water based on recharge and return flow from domestic use for the two dimensional domain is range approximately from 1593 to $1104 \mathrm{~m}^{3} / \mathrm{yr}$, while the total natural discharge from the domain ranged from 838 and $373 \mathrm{~m}^{3} / \mathrm{yr}$ for an average and dry hydrological year respectively. The present abstraction is under the safe yield and keeps the aquifer sustainable. However, the predicted future pumping based on population expansion demonstrate negative water balance, exceeding both recharge and safe yield of the aquifer system, thus groundwater mining is taking place causing wells to be contaminated from saline water from sea and the lagoon. Therefore the safe yield of the aquifer for the average hydrological year, $0.37 \mathrm{~m}^{3} / \mathrm{m}^{2}$ and $0.18 \mathrm{~m}^{3} / \mathrm{m}^{2}$ for a dry hydrological year to be maintained for the sustainability of the system. However, the wells have to be at least $750 \mathrm{~m}$ inland from the sea and lagoon respectively. This study also showed that the potential changes to climatic regime by 2050 could further impact the sustainability of the sandy aquifers in the eastern coast. It was found that as a consequence of less recharge to aquifers, water tables could be lower causing an acceleration of saltwater intrusion on contamination of wells near the coast.

\section{ACKNOWLEDGEMENT}

First and foremost, special thanks go to PFRA, Canada who funded this study. MV likes to express gratitude to Lasantha Perera in the Water Resources Board, staff of the Climate and Radar sections of the Meteorological Department, Staff of the groundwater investigation unit of the $\mathrm{Na}-$

Table 4. Ground Water Balance for the Average and Dry Hydrological Year for the Model Domain $\left(4000 \mathrm{~m}^{2}\right)$

\begin{tabular}{|c|c|c|c|c|c|}
\hline \multirow{4}{*}{$\begin{array}{l}\text { Present estimation (present } \\
\text { pumping and recharge) }\end{array}$} & \multicolumn{5}{|c|}{ Parameters $\left(\mathbf{m}^{3} / \mathbf{y r}\right)$} \\
\hline & \multicolumn{3}{|c|}{ Discharge } & \multicolumn{2}{|c|}{ Recharge } \\
\hline & \multicolumn{2}{|c|}{ Natural } & \multirow{2}{*}{ Artificial (pumping) } & \multirow{2}{*}{ Natural (from rainfall) } & \multirow{2}{*}{ Artificial (return flow) } \\
\hline & Discharge to sea & Discharge to lagoon & & & \\
\hline Average year & 420.0 & 418.0 & 730.0 & 1347.0 & 219.0 \\
\hline
\end{tabular}


tional Water Supply and Drainage Board for their kind support given for providing necessary data.

\section{REFERENCES}

[1] Sophocleous MA. From safe yield to sustainable development of water resources: the Kansas experience. J Hydrol 2000; 235(1-2): 27-43.

[2] Voudouris KS. Groundwater balance and safe yield of the coastal aquifer system in NEastern Korinthia, Greece. Appl Geogr 2006; 26: 291-311.

[3] Alley WM, Leake SA. The journey from safe yield to sustainability. Groundwater 2004; 42(1): 12-16.

[4] Dottridge J, Jaber NA. Groundwater resources and quality in northeastern Jordan: Safe yield and sustainability. Appl Geogr 1999; 19: 313-23.

[5] Jacobs KL, Holway JM. Managing for sustainability in an arid climate; lessons learned from 20 years of groundwater management in Arizona, USA. Hydrogeol J 2004; 12(1): 1431-2174.

[6] IPCC, Climate change. Climate change 2007: the physical science basis. IPCC Working Group I, Fourth Assessment Report: Summary for Policymakers. IPCC, Geneva 2007.

[7] Panabokke CR, Pathirana SRK, Wijekoon D. Water quality of agro-wells in the coastal sand aquifer in Trincomalee District. Symposium proceedings on the Use of Groundwater for Agriculture in Sri Lanka, University of Peradeniya, Sri Lanka 2002; pp. 85-98.

[8] Carter TR, Hulme M, Lal M, Prepared: IPCC-TGCIA, Guidelines on the use of Scenario Data for Climate Impact and Adaptation Assessment, Version 1. Intergovernmental Panel on Climate Change, Task Group on Scenarios for Climate Impact Assessment 1999.

[9] De Silva CS, Weatherhead EK, Knox JW, Rodriguez-Diaz JA. Predicting the impacts of climate change; a case study of paddy irrigation water requirements in Sri Lanka. Agric Water Manage 2007; 93: 19-29.

[10] Panabokke CR, Perera APGRL. Groundwater resources of Sri Lanka. World water Assessment Program, Sri Lanka 2005.

[11] Illangasekare T, Tyler SW, Clement TP, Villholth KG, Perera APGRL, Obeysekera J, Gunatilaka A, Panabokke CR, Hyndman DW, Cunningham KJ, Kaluarachchi JJ, Yeh WWG, Van Genuchten, MR, Jensen KH. Impacts of the 2004 Tsunami on Groundwater Resources in Sri Lanka. Water Resourc Res 2006; 42: W05201.

[12] Nadarajah K. Well inventory in the Nilaveli-Kuchchaweli area. Technical Paper 17. Integrated Agricultural Food Security Program. Trincomalee, Sri Lanka 2002.

[13] Naik PK, Awasthi AK. Groundwater resources assessment of the Konya river basin, India. Hydrogeol J 2003; 11: 582-94.

[14] Vithanage M. Effect of tsunami on coastal aquifers: Field studies and tank experiments, PhD thesis, Faculty of Science, University of Copenhagen, Denmark 2009.
[15] Wickremaratne HU. Use of groundwater for coastal water supply schemes, minimizing the salinity problem; A case study at Kattankudy in Batticaloa District, Sri Lanka. MSc Thesis. Post Graduate Institute of Science, University of Peradeniya, Peradeniya, Sri Lanka 2004.

[16] Hoareau J, Guerin R, Vouillamoz JM, Vithanage M. Sustainable development of water resources, water supply and environmental sanitation. $32^{\text {nd }}$ WEDC International Conference. Colombo, Sri Lanka 2006.

[17] Jeong $\mathrm{CH}$. Effect of land use and urbanization on hydrochemistry and contamination of groundwater from Taejon area, Korea. J Hydrol 2001; 253: 194-210.

[18] Mahendran S, Jeyakumar P, Premanatharajah P, Thiruchelvam, T. Study on groundwater quality of some selected wells during dry season in the municipal council area of Batticaloa. Proceedings of first annual research sessions- Eastern University of Sri Lanka 2000; pp. 53-61.

[19] Vaheesar K. Nitrate and fluoride content in groundwater in the Batticaloa District. J Sci (Eastern University of Sri Lanka) 2002; 2(1): 9-15.

[20] Panabokke CR, Pathirana SRK. Water quality monitoring in the coastal area of Tincomalee District. Technical Paper 16. In: Integrated Agricultural Food Security Program. Trincomalee, Sri Lanka 2003.

[21] Jeyakumar P, Premanatharajah P, Mahendran S. Water quality of agro-wells in the coastal area of the Batticaloa District. Symposium proceedings on the Use of Groundwater for Agriculture in Sri Lanka. Peradeniya, Sri Lanka 2002; pp. 99-107.

[22] Vaheesar K, Mahendran T, Priyantha N. Analytical studies on irrigation water at Kaluthaweli in the Batticaloa District. J Sci (Eastern University of Sri Lanka) 2000; 1(1): 10-15.

[23] Kipp KL. HST3D: A computer code for simulation of heat and solute transport in three dimensional groundwater flow systems. Water resources investigation report, USGS, Denver, Colorado 1987; pp. 86-4095.

[24] Allan GR, Pereira LS, Raes D, Smith M. Crop evapotranspiration; guidelines for computing crop water requirements. FAO Irrigation and Drainage Paper 56, FAO, Rome 1998.

[25] Šimůnek J, Van Genuchten MT, and Šejna M. The HYDRUS-1D Software Package for Simulating the Movement of Water, Heat, and Multiple Solutes in Variably Saturated Media, Version 3.0, HYDRUS Software Series 1, Department of Environmental Sciences, University of California Riverside, Riverside, California, USA 2005

[26] Konikow LF. Numerical models of groundwater flow and transport. In: Manual on Mathematical Models in Isotope Hydrology. IAEA-TECDOC-910. International Atomic Energy Agency, Vienna, Austria, 1996; pp. 59-112.

(C) Vithanage et al.; Licensee Bentham Open.

This is an open access article licensed under the terms of the Creative Commons Attribution Non-Commercial License (http://creativecommons.org/licenses/by-nc/3.0/) which permits unrestricted, non-commercial use, distribution and reproduction in any medium, provided the work is properly cited. 